\title{
Weed Control in CoRn Via INTERCROPPING WITH GliRICIDia SOWN BY BROADCASTING ${ }^{1}$
}

\author{
Controle de Plantas Daninhas no Milho por Meio da Consorciação com Gliricidia Semeada a \\ Lanço
}

\author{
OLIVEIRA, A.M. ${ }^{2}$, SILVA, P.S.L. ${ }^{3}$, ALBUQUERQUE, C.C. ${ }^{4}$, AZEVEDO, C.M.S.B. ${ }^{5}$, CARDOSO, M.J. ${ }^{6}$ \\ and OLIVEIRA, O.F. ${ }^{7}$
}

\begin{abstract}
There has been interest in reducing the use of herbicides for weed control in order to decrease environmental degradation problems. The objective of this study was to evaluate the effects of gliricidia planting density sown by broadcasting and intercopping on green ear and corn grain yield as well as on weed control. A randomized block design with split-plots and five replicates were adopted. Cultivars AG 1051, BM 2022, and BM 3061, assigned to plots, were submitted to the following treatments: no hoeing, two hoeings (at 20 and 40 days after sowing), and intercropped with gliricidia sown at densities of 10 and 20 seeds $\mathrm{m}^{-2}$. Thirty weed species occurred in the experiment area, with Cucumis anguria as the most frequent ones. Cultivar BM 2022 was the best for the total number of ears (TNE) and number (NMHE) and weight of marketable husked ears. Together with cultivar AG 1051, this cultivar had the highest total weight and marketable unhusked ear weight (MUEW). However, the cultivars did not differ with respect to grain yield (GY). The highest green ear and corn grain yield and weed control percentages were obtained with two hoeings; in MUEW, NMHE and GY, intercropping provided intermediate means in comparison with those obtained in hoed and non-hoed plots, indicating that gliricidia was partially beneficial to corn. Increased gliricidia seeding density heightened the benefits to corn (TNE and MUEW). The lack of hoeing produced the poorest green ear and grain yields.
\end{abstract}

Keywords: Zea mays, Gliricidia sepium, green ear yield, grain yield.

RESUMO - Existe interesse na redução do uso de herbicidas, visando-se a diminuição de problemas de degradação ambiental. O objetivo do trabalho foi avaliar os efeitos da densidade da gliricídia, semeada a lanço e em consorciação, sobre os rendimentos de espigas verdes e de grãos do milho e sobre o controle de plantas daninhas. Utilizou-se o delineamento de blocos ao acaso com parcelas subdivididas e cinco repetições. As cultivares AG 1051, BM 2022 e BM 3061, plantadas nas parcelas, foram submetidas aos seguintes tratamentos: sem capinas, duas capinas (aos 20 e 40 dias após a semeadura) e consorciação com a gliricidia, semeada nas densidades de 10 e 20 sementes $\mathrm{m}^{2}$. Trinta espécies de plantas daninhas ocorreram na área experimental, sendo Cucumis anguria a mais frequente. A cultivar BM 2022 foi a melhor quanto ao número total de espigas (NTE) e número (NEDC) e peso de espigas despalhadas comercializáveis. Essa cultivar apresentou, juntamente com a cultivar AG 1051, os maiores pesos total e de espigas empalhadas comercializáveis (PEEC). Todavia, as cultivares não diferiram quanto ao rendimento de grãos (RG). Os maiores rendimentos de milho verde e de grãos e de controle das plantas daninhas foram obtidos com duas capinas; a consorciação propiciou em PEEC, NEDC e RG médias intermediárias às obtidas nas parcelas capinadas e nãocapinadas, indicando que a gliricidia foi parcialmente benéfica ao milho. O aumento da densidade de semeadura da gliricidia aumentou os beneficios para o milho (NTE e PEEC). A ausência de capinas propiciou os piores rendimentos de espigas verdes e de grãos.

Palavras-chave: Zea mays, Gliricidia sepium, rendimento de espigas verdes, rendimento de grãos.

1 Recebido para publicação em 31.8.2010 e aprovado em 30.3.2011.

2 Doctorate program student, Universidade Federal do Semi-Árido - UFERSA, Caixa Postal 137, 59600-970 Mossoró-RN, <marcuspitter@bol.com.br>; ${ }^{3}$ Professor, UFERSA, CNPq fellow, <paulosergio@ufersa.edu.br>; ${ }^{4}$ Universidade do Estado do Rio Grande do Norte - UERN, Caixa Postal 70, 59600-970 Mossoró-RN, <cycavalcanti@gmail.com>; ${ }^{5}$ Professor, UFERSA, <celicina@gmail.com>; ${ }^{6}$ Researcher, Embrapa Meio-Norte, 64006-220 Teresina-PI, <miltoncardoso@cpamn.embrapa.br>; ${ }^{7}$ UFERSA (Former professor), <odaci@uol.com.br >; ${ }^{8}$ Professor, UFERSA, <clarete@ufersa.edu.br>.

Planta Daninha, Viçosa-MG, v. 29, n. 3, p. 535-543, 2011 


\section{INTRODUCTION}

Herbicides have simplified weed control and started to be extensively used, replacing cultural weed control methods in several regions. However, the extensive use of herbicides has resulted in the selection of weed biotypes resistant to these products. Such biotypes already exist at low frequencies in cultivated areas, but being resistant to herbicides, at each generation they produce a higher number of offspring than non-resistant biotypes. Consequently, after a few generations, the proportion of resistant biotypes present in the weed population tends to increase. In addition, herbicides have become an environmental contamination factor. Cultural practices leading to a more sustainable weed control studied in the past have again become interesting and are once again being studied (Moraes et al., 2009), including intercrops (Borghi et al., 2008; Silva et al., 2009a, b).

A cover crop, that is, a crop used in intercropping for weed control purposes, accomplishes such control in a number of ways. A rapid occupation of free space between the plant rows of the main crop reduces weed germination, growth, and development. The germination of weed seeds can be inhibited due to light interception or secretion of allelochemicals in the cover crop. After weeds are established, competition for resources becomes the main mechanism of weed suppression in the cover crop (Hollander et al., 2007). The decrease in weed incidence in corn via intercropping is dependent on several factors, including cultivar, weather conditions (Kuchinda et al., 2003), sowing season, intercropped species (Skóra Neto, 1993), and fertilizer applied (Olasantan et al., 1994).

Another factor that influences weed control in intercrops is the planting density of the crop employed to control weeds via intercropping. All plant spacing tested between sweet potato (Ipomoea batatas) plants suppressed weed growth and increased grain yield in corn in comparison to non-hoed corn grown as a monocrop (Aladesanwa \& Adigun, 2008). Cucurbita maxima intercropped with corn at various densities reduced total weed biomass and the biomass of the dominant weeds Amaranthus retroflexus and
Convolvulus arvensis, but corn yield was not necessarily reduced in the intercrop, except at the highest density of the cucurbit or under limited moisture (Fujiyoshi et al., 2007).

Gliricidia (Gliricidia sepium) is a tree legume native to Mexico (Drumond \& Carvalho Filho, 2005). The use of gliricidia branches as soil mulch did not have an allelopathic effect on corn and bean (Phaseolus vulgaris), but significantly decreased the population of some weed species (Obando, 1987). Gliricidia branches used as soil mulch reduced weed density and weed biomass (Kamara et al., 2000). These results have encouraged an investigation on the effects of gliricidia as an intercrop on weed control in corn. That investigation showed that the legume controlled, to a certain extent, the weeds (Silva et al., 2009b). In that study, gliricidia was grown by transplantating to ensure uniform germination and fast establishment in the field. However, transplanting is costly since it involves labor for seedling production and transplanting. Therefore, it is interesting to evaluate whether direct sowing of gliricidia would still provide control of weeds.

Another management practice, which can help reduce the use of herbicides, is the use of cultivars that can tolerate or suppress weeds more effectively. Variety differences in weed controlling capacity have been reported for many crops, including corn (Begna et al., 2001). Plant height, leaf development rate, leaf area index, and leaf distribution in the canopy have been cited as the most important weedsuppressing traits (Sinoquet \& Caldwell, 1995); but it is possible that other traits, including those related to the root system, may also influence suppression.

The objective of this study was to evaluate the effects of gliricidia seeding density by broadcasting, intercropped with corn, on weed control, green ear yield, and grain yield of corn cultivars.

\section{MATERIAL AND METHOD}

The research was conducted at Fazenda Experimental "Rafael Fernandes" (Experimental Farm), Universidade Federal Rural do Semi-Árido - UFERSA, during the period from March to June 2008. The farm is 
located in the district of Alagoinha, $20 \mathrm{~km}$ away from the municipal seat of Mossoró-RN (latitude $5^{\circ} 11^{\prime} \mathrm{S}$, longitude $37^{\circ} 20^{\prime} \mathrm{W}$, and $18 \mathrm{~m}$ elevation). According to Gaussen's bioclimatic classification, the climate in the Mossoró region is classified as type 4ath, or distinctly xerothermic, that is, tropical hot with a pronounced, long dry season, lasting from seven to eight months and with a xerothermic index between 150 and 200. The mean maximum temperature in the region is between 32 and $35{ }^{\circ} \mathrm{C}$, with June and July being the coolest months, while the mean annual precipitation is around $670 \mathrm{~mm}$ (Carmo Filho \& Oliveira, 1989).

The soil in the experiment area is classified as a Red-Yellow Argisol, according to the Brazilian Soil Classification System (Embrapa, 1999), and as a Ferric Lixisol, according to the Soil Map of the World (FAO, 1988). Weed control in the area where corn or cowpea (Vigna unguiculata) was previously grown has always been achieved by means of two hoeings, performed at 20 and 40 days after seeding. No phytosociological weed survey prior to the experiment installation was performed in the area. The analysis of a soil sample taken from the experiment area indicated the following: $\mathrm{pH}=6.4 ; \mathrm{Ca}^{2+}=1.50 \mathrm{cmol}_{\mathrm{c}} \mathrm{dm}^{-3}$; $\mathrm{Mg}^{2+}=0.60 \mathrm{cmol}_{\mathrm{c}} \mathrm{dm}^{-3} ; \mathrm{K}^{+}=0.17 \mathrm{cmol}_{\mathrm{c}} \mathrm{dm}^{-3}$; $\mathrm{Na}^{+}=0.04 \mathrm{cmol}_{\mathrm{c}} \mathrm{dm}^{-3} ; \mathrm{Al}^{3+}=0.00 \mathrm{cmol}_{\mathrm{c}} \mathrm{dm}^{-3}$; $\mathrm{P}=38 \mathrm{mg} \mathrm{dm}^{-3}$; Org. Mat. $=10.0 \mathrm{~g} \mathrm{~kg}^{-1}$.

The soil was tilled with a tractor by means of two harrowings and received $1 / 3$ of total $\mathrm{N}$ applied $\left(90 \mathrm{~kg}^{-1}\right), 60 \mathrm{~kg} \mathrm{P}_{2} \mathrm{O}_{5}$, and $30 \mathrm{~kg} \mathrm{~K}_{2} \mathrm{O}$ per ha, as planting fertilization. The remaining $\mathrm{N}$ was applied in equal parts after each hoeing. Ammonium sulfate, single superphosphate, and potassium chloride were used as sources of $\mathrm{N}, \mathrm{P}$, and $\mathrm{K}$, respectively. Plant rows were spaced $1.0 \mathrm{~m}$ apart, and pits in the same row were spaced $0.40 \mathrm{~m}$ apart. Seeding was accomplished manually using four seeds per pit. A thinning operation was performed 20 days after planting, leaving the two more vigorous plants in each pit; the experiment was thus left with a programmed sowing density of 50 thousand plants ha ${ }^{-1}$.

The fall armyworm (Spodoptera frugiperda), the main pest of the corn crop in the region, was controlled with sprays of 0.0-diethyl-0,3,5,6-trichloro-2-pyridiny1 thiophosphate $\left(0.4 \mathrm{~L} \mathrm{ha}^{-1}\right)$, using a backpack sprayer.

The experiment was carried out under dryland conditions, but received sprinkler irrigation as needed, with experimental plots arranged perpendicularly to the row of sprinklers. The water depth required for corn $(5.3 \mathrm{~mm})$ was calculated considering an effective depth of the root system of $0.40 \mathrm{~m}$. Irrigation time was based on water retained in the soil at a tension of $0.40 \mathrm{MPa}$. Irrigations were performed three times a week, starting after seeding and finishing five days before harvesting the mature ears.

A randomized block experimental design with split-plots and five replicates were adopted. Each subplot consisted of four rows $6.0 \mathrm{~m}$ in length each. The usable area was considered as the space occupied by the two central rows, where we eliminated the plants from one of the pits at each end. Cultivars AG 1051, BM 2022, and BM 306, planted in the plots, were submitted to the following treatments, assigned to the subplots: no hoeing, two hoeings (at 20 and 40 days after planting), and intercropping with gliricidia. Cultivars were used in the plots and weed control treatments were applied to the subplots. Weedings were performed with a hoe. In the intercropped treatment, gliricidia was sown by broadcasting at corn planting between the corn rows at two sowing densities (10 and 20 seeds $\mathrm{m}^{-2}$ ). The gliricidia seeds, with a germination rate of practically $100 \%$, were broadcast on the soil surface as uniformly as possible between the corn rows, and incorporated with a rake.

One of the two rows in the usable area of each subplot was selected at random to evaluate corn green yield, while the other one was used to evaluate mature corn yield. Green corn yield was evaluated by the total number and weight of ears and the number and weight of marketable ears, both unhusked and husked. Marketable unhusked ears were considered as those with appearance suitable for commercialization and length equal to or above $22 \mathrm{~cm}$. Marketable husked ears were considered as those that displayed health and grain set suitable for commercialization, and length equal to or above $17 \mathrm{~cm}$. Evaluations 
were made in mature corn for grain yield and its components. The ears produced in the usable area of each subplot were harvested when the grain achieved a water content of about $20 \%$, and were then placed to dry and subsequently threshed out manually. The numbers of ears thus obtained and their grain allowed to estimate the number of ears per hectare and grain yield. Number of kernels per ear was estimated based on the kernels counted in ten of those ears. One hundredkernel weight was obtained from five samples containing 100 kernels each.

After harvesting the mature corn, data were obtained from corn plant height and corn ear height, gliricidia height, gliricidia stand, weed dry matter, and weed floristic composition. Plant height and ear height were measured in all plants of the row that had been selected to evaluate grain yield. The distance from ground level to the point of insertion of the tallest leaf blade was considered as plant height; ear height was measured from ground level to the base of the tallest ear (first ear, in the case of prolific plants). The gliricidia plants present in the area between the two central rows of each experiment unit were counted and measured. Gliricidia plant height was considered as the distance from ground level to the crown top of each plant. The weeds found in a $1.0 \times 1.0 \mathrm{~m}$ area, established at random in the central part of the subplot, were cut even with the ground, identified, and weighed. Dry biomass was estimated by grinding samples weighing around $500 \mathrm{~g}$, which were placed to dry in a forced air circulation oven adjusted to a temperature between 70 and $80^{\circ} \mathrm{C}$.

The occurrence index, defined by the ratio between the number of units where a given species occurred and the total number (60) of experimental units in the experiment, was calculated after the weed species found in each experimental unit had been identified.

The data were submitted to analysis of variance using software (SAEG) developed by Universidade Federal de Viçosa (Ribeiro Junior, 2001), while regression analyses were made with the software developed by Jandel (1992). The data were tested for homogeneity of variances prior to the statistical analyses (Bartlett, 1937). Since count data tend to follow the Poisson distribution, gliricidia stand data were transformed to square root prior to the statistical analysis (Bartlett, 1947). The means were compared at $5 \%$ probability by Tukey's test whenever the $\mathrm{F}$ test values from the analysis of variance were significant. Regression analyses were run to detect potential effects of increased gliricidia seeding density (independent variable) on the traits evaluated (dependent variable). In these analyses, non-hoed plots were considered as "seeding density zero". A regression equation was selected based on the following criteria: biological explanation of the phenomenon observed, simplicity of the equation, significance of the coefficients at $5 \%$ probability by Student's t-test and value of coefficient of determination.

\section{RESULTS AND DISCUSSION}

Thirty weed species occurred in the experiment (Table 1) where most of them belong to family Poaceae. The weed population in a given area depends on several factors (weed seed bank, soil, climate, previous crops, etc.), and although the population comprises different species, few of them are predominant, corresponding to 70 to $90 \%$ of the total species (Buhler, 1999). Some species occurred more frequently than others (Table 1). The species Cucumis anguria, for example, occurred in $80 \%$ of the experiment units, while most of the species occurred at frequencies around $2 \%$ (Table 1).

There were no effects of the cultivars $\mathrm{x}$ weed control interaction on the traits evaluated. For this reason, only means for the main effects of both treatment groups are presented here.

No differences were found between dry matters of the above-ground part of weeds that occurred in plots of the three cultivars (mean $194 \mathrm{~g} \mathrm{~m}^{-2}, \mathrm{CV}_{\text {plots }}=41.1 \%$ ). Also, there were no differences between non-hoed and intercropped plots for dry matter of the aboveground part of weeds (mean $236.3 \mathrm{~g} \mathrm{~m}^{-2}$, $\mathrm{CV}_{\text {subplots }}=43.8 \%$ ), but this mean was significantly higher than the mean obtained in hoed plots $\left(68.7 \mathrm{~g} \mathrm{~m}^{-2}\right)$. 
Table 1 - Index of occurrence (number of plots where a given weed species occurred/total number of experiment plots) of weed species with their respective families, identified in experiment plots of corn. Mossoró-RN, 2008

\begin{tabular}{|c|c|c|c|}
\hline $\begin{array}{c}\text { Order } \\
\text { number }\end{array}$ & Species & Family & $\begin{array}{c}\text { Index of occurrence } \\
(\%)\end{array}$ \\
\hline 1 & Acanthospermum hispidum DC. & Asteraceae & 1,7 \\
\hline 2 & Adenocalymma sp. & Bignoniaceae & 1,7 \\
\hline 3 & Alternanthera tenella Colla & Amaranthaceae & 73,3 \\
\hline 4 & Amaranthus viridis $\mathrm{L}$. & Amaranthaceae & 1,7 \\
\hline 5 & Blainvillea acmella (L.) Philipson & Asteraceae & 8,3 \\
\hline 6 & Borreria verticillata (L.) G. Mey & Rubiaceae & 1,7 \\
\hline 7 & Cenchrus echinatus L. & Poaceae & 5,0 \\
\hline 8 & Chamaecrista $\mathrm{sp}$. & Caesalpiniaceae & 1,7 \\
\hline 9 & Commelina benghalensis L. & Commelinaceae & 60,0 \\
\hline 10 & Cucumis anguria $\mathrm{L}$. & Cucurbitaceae & 80,0 \\
\hline 11 & Cyperus rotundus $\mathrm{L}$. & Cyperaceae & 1,7 \\
\hline 12 & Dactyloctenium aegyptium (L.) Willd. & Poaceae & 1,7 \\
\hline 13 & Desmodium glaglabrum (Mill.) DC. & Fabaceae & 3,3 \\
\hline 14 & Digitaria sanguinalis Scop. & Poaceae & 10,0 \\
\hline 15 & Euphorbia hirta L. (= Chamaesyce hirta (L.) Millsp.) & Euphorbiaceae & 1,7 \\
\hline 16 & Herissantia crispa (L.) Brizicky & Malvaceae & 1,7 \\
\hline 17 & Hyptis suaveolens (L.) Poit. & Lamiaceae & 1,7 \\
\hline 18 & Indigofera microcarpa Desv. & Fabaceae & 1,7 \\
\hline 19 & Ludwigia $\mathrm{sp}$ & Onagraceae & 1,7 \\
\hline 20 & Ipomoea bahiensis Willd. Ex Roem and Schult & Convolvulaceae & 5,0 \\
\hline 21 & Merremia aegyptia (L.) Urb. & Convolvulaceae & 8,3 \\
\hline 22 & Merremia cissoides (Lam.) Hallier f. & Convolvulaceae & 3,3 \\
\hline 23 & Panicum maximum Jacq. (= Urochloa maxima (Jacq.) R. D. Webster) & Poaceae & 1,7 \\
\hline 24 & Physalis angulata $\mathrm{L}$. & Solanaceae & 1,7 \\
\hline 25 & Phyllanthus amarus Schumach. and Thonn. & Euphorbiaceae & 1,7 \\
\hline 26 & Richardsonia grandiflora Cham. and Schltdl. & Rubiaceae & 1,7 \\
\hline 27 & Senna sp. & Caesalpiniaceae & 1,7 \\
\hline 28 & Sida spinosa $\mathrm{L}$. & Malvaceae & 1,7 \\
\hline 29 & Stachytarpheta sp. & Verbenaceae & 1,7 \\
\hline 30 & Waltheria indica L. & Sterculiaceae & 1,7 \\
\hline
\end{tabular}

The mean densities of gliricidia plants between rows in cultivars AG 1051, BM 2061, and BM 2022 at the end of the experiment were $3.6 b ; 4.5 a b$; and $6.3 a$, respectively (where means followed by the same letter do not differ from one another, at 5\% probability by Tukey's test). Therefore, the corn cultivars differed in their competitive ability with gliricidia. This fact indicates the complexity of relations between species, when weed control is sought via intercropping. Some of the plants of the intercropped species selected to benefit corn may be eliminated by some corn cultivars. This may also help explain the discrepancies between studies on weed control by intercropping. A higher gliricidia seeding density $\left(20\right.$ seeds $\left.\mathrm{m}^{-2}\right)$ provided a higher final stand (5.65 plants $\left.\mathrm{m}^{-2}\right)$ than the stand obtained at the lowest $\left(10\right.$ seeds $\left.\mathrm{m}^{-2}\right)$ seeding density
(3.93 plants $\mathrm{m}^{-2}$ ). The $\mathrm{CV}_{\text {plots }}$ and $\mathrm{CV}_{\text {subplots }}$ values for the final gliricidia stand were 40.3 and $40.7 \%$, respectively. There was no effect of cultivars or gliricidia seeding density on mean height of this legume plant (mean $44.6 \mathrm{~cm}, \mathrm{CV}_{\text {plots }}=15.8$ and $\mathrm{CV}_{\text {subplots }}$ = 24.6).

Cultivar BM 2022 was the best for three (total number of ears and number and weight of marketable husked ears) among the six traits used to evaluate green corn yield (Table 2). In addition, along with cultivar AG 1051, this cultivar had the highest total weight and marketable unhusked ear weight (Table 2). There were no differences between cultivars for the number of marketable green ears, indicating that, from the total number of ears harvested, higher numbers of ears were 
discarded in the most productive cultivars, in terms of ear total number.

There were no differences between weed control methods with respect to total number of green ears (Table 3). For the other traits, two hoeings provided higher yields than the other treatments, which did not differ from one another (Table 3). As regards to weight of marketable unhusked ears and number of marketable husked ears, intercropping with gliricidia produced intermediate yields in relation to non-hoeing and two-hoeing treatments.

Cultivar AG 1051 had the highest plant height and ear height values (Table 4). Plant height is considered an important trait in competition. Although it did not influence weed dry matter, the highest plant height obtained in cultivar AG 1051 may have contributed towards the previously reported reduction in gliricidia stand. There were no differences between cultivars as to grain yield, although they differed with respect to the three main yield components (Table 4). The compensation that occurs among these components is well known. For example, cultivar BM 2022 had the highest numbers of ears per hectar and kernels per ear (in this case, together with cultivar AG 1051), but showed the smallest weight of 100 kernels. Similar compensations occurred with the other cultivars (Table 4).

Not always the best cultivars for green corn production (Table 2) are also the best for grain yield (Table 4). Each product is evaluated differently. Ears unsuitable for sale as green corn (very small, with poor grain set, attacked by pests, etc.) can be perfectly used for mature grain (Silva et al., 2009b).

Weed control method did not influence plant height and corn ear height, but grain yield was higher in hoed plots, smaller in nonhoed plots, and intermediate in plots intercropped with gliricidia (Table 5). These

Table 2 - Means (of five replicates and four weed control methods) for green ear yield in corn cultivars ${ }^{1 /}$

\begin{tabular}{|c|c|c|c|c|c|c|}
\hline \multirow[t]{2}{*}{ Cultivar } & \multicolumn{2}{|c|}{ Green ear totals $\mathrm{ha}^{-1}$} & \multicolumn{2}{|c|}{$\begin{array}{l}\text { Marketable unhusked } \\
\text { green ears ha }\end{array}$} & \multicolumn{2}{|c|}{ Marketable husked green ears ha } \\
\hline & Number & Weight (kg) & Number & Weight (kg) & Number & Weight (kg) \\
\hline BM 2022 & $50,613 \mathrm{a}$ & $13,542 \mathrm{a}$ & $47,261 \mathrm{a}$ & $12,979 \mathrm{a}$ & $39,213 \mathrm{a}$ & $7,510 \mathrm{a}$ \\
\hline AG 1051 & $48,889 \mathrm{ab}$ & $13,243 \mathrm{a}$ & $44,776 \mathrm{a}$ & $12,753 \mathrm{a}$ & $29,692 \mathrm{~b}$ & $6,233 \mathrm{~b}$ \\
\hline BM 3061 & $47,939 \mathrm{~b}$ & $11,940 \mathrm{~b}$ & $44,112 \mathrm{a}$ & $11,408 \mathrm{~b}$ & $34,738 \mathrm{ab}$ & $6,100 \mathrm{~b}$ \\
\hline CVplots, \% & 5.7 & 9.8 & 12.7 & 12.5 & 17.5 & 19.2 \\
\hline
\end{tabular}

${ }^{1 /}$ In the columns, means followed by the same letter do not differ from one another at $5 \%$ probability by Tukey's test.

Table 3 - Means (of five replicates and three cultivars) for green ear yield in corn cultivars submitted to weed control methods ${ }^{\underline{1}}$

\begin{tabular}{|c|c|c|c|c|c|c|c|c|}
\hline \multirow{3}{*}{$\begin{array}{l}\text { Weed control } \\
\text { method }\end{array}$} & \multicolumn{2}{|c|}{ Green ear totals ha ${ }^{-1}$} & \multicolumn{3}{|c|}{ Marketable unhusked green ears $\mathrm{ha}^{-1}$} & \multicolumn{3}{|c|}{ Marketable husked green ears $\mathrm{ha}^{-1}$} \\
\hline & \multirow[b]{2}{*}{ Number } & \multirow[b]{2}{*}{$\begin{array}{c}\text { Weight } \\
(\mathrm{kg})\end{array}$} & \multirow[b]{2}{*}{ Number } & \multicolumn{2}{|c|}{ Weight } & \multicolumn{2}{|c|}{ Number } & \multirow[b]{2}{*}{$\begin{array}{c}\text { Weight } \\
(\mathrm{kg})\end{array}$} \\
\hline & & & & $\begin{array}{l}\text { Absolute } \\
(\mathrm{kg})\end{array}$ & $\begin{array}{c}\text { Relative } \\
(\%)\end{array}$ & $\begin{array}{l}\text { Absolute } \\
(\mathrm{kg})\end{array}$ & $\begin{array}{c}\text { Relative } \\
(\%)\end{array}$ & \\
\hline Two hoeings & $50,556 \mathrm{a}$ & $15,489 \mathrm{a}$ & $49,011 \mathrm{a}$ & $15,274 \mathrm{a}$ & 136 & $40,633 \mathrm{a}$ & 136 & $8,462 \mathrm{a}$ \\
\hline $\begin{array}{l}\text { Intercropped with } \\
\text { gliricidia, sown at } \\
10 \text { seeds } \mathrm{m}^{-2}\end{array}$ & $48,818 \mathrm{a}$ & $12,468 \mathrm{~b}$ & $44,058 \mathrm{~b}$ & $11,847 \mathrm{~b}$ & 105 & $35,741 \mathrm{ab}$ & 120 & $6,563 \mathrm{~b}$ \\
\hline $\begin{array}{l}\text { Intercropped with } \\
\text { gliricidia, sown at } \\
20 \text { seeds } \mathrm{m}^{-2}\end{array}$ & $48,877 \mathrm{a}$ & $12,020 \mathrm{~b}$ & $44,119 \mathrm{~b}$ & $12,470 \mathrm{ab}$ & 111 & $32,008 \mathrm{~b}$ & 107 & $6,030 \mathrm{~b}$ \\
\hline No hoeing & $48,335 \mathrm{a}$ & $11,656 \mathrm{~b}$ & $44,344 \mathrm{~b}$ & $11,261 \mathrm{~b}$ & 100 & $29,807 \mathrm{~b}$ & 100 & $5,402 \mathrm{~b}$ \\
\hline CVsubplots, \% & 4.7 & 11.1 & 12.7 & & & & & 18.9 \\
\hline
\end{tabular}

${ }^{1 /}$ In the columns, means followed by the same letter do not differ from one another at $5 \%$ probability by Tukey's test. 
Table 4 - Means (of five replicates and four weed control methods) for plant height, ear height, and grain yield and its components in corn cultivars ${ }^{1 /}$

\begin{tabular}{|c|c|c|c|c|c|c|}
\hline \multirow{2}{*}{ Cultivar } & \multicolumn{2}{|c|}{ Heights $(\mathrm{cm})$} & \multirow{2}{*}{$\begin{array}{l}\text { Grain yield } \\
\left(\mathrm{kg} \mathrm{ha}^{-1}\right)\end{array}$} & \multirow{2}{*}{$\begin{array}{l}\text { Number of ears } \\
\text { ha }^{-1}\end{array}$} & \multirow{2}{*}{$\begin{array}{c}\text { Number } \\
\text { of kernels } \\
\text { ear }^{-1}\end{array}$} & \multirow{2}{*}{$\begin{array}{l}\text { 100-kernel } \\
\text { weight }(\mathrm{g})\end{array}$} \\
\hline & Plant & Ear & & & & \\
\hline BM 2022 & $195 \mathrm{~b}$ & $95 \mathrm{~b}$ & $6,275 \mathrm{a}$ & $50,087 \mathrm{a}$ & $414.7 \mathrm{a}$ & $32.8 \mathrm{~b}$ \\
\hline AG 1051 & $207 \mathrm{a}$ & $115 \mathrm{a}$ & $6,122 \mathrm{a}$ & $48,820 \mathrm{ab}$ & $415.0 \mathrm{a}$ & $35.0 \mathrm{a}$ \\
\hline BM 3061 & $185 \mathrm{~b}$ & $93 \mathrm{~b}$ & $5,816 \mathrm{a}$ & $48,107 \mathrm{~b}$ & $360.3 \mathrm{~b}$ & $34.7 \mathrm{a}$ \\
\hline CVplots, \% & 6.5 & 5.5 & 14.3 & 3.8 & 11.0 & 5.8 \\
\hline
\end{tabular}

${ }_{1 /}^{1 /}$ In the columns, means followed by the same letter do not differ from one another at $5 \%$ probability by Tukey's test.

Table 5 - Means (of five replicates and three cultivars) for plant height, ear height, and grain yield and its components in corn cultivars $^{\mathbf{1}^{\prime}}$

\begin{tabular}{|c|c|c|c|c|c|c|c|c|}
\hline \multirow{3}{*}{$\begin{array}{l}\text { Weed control } \\
\text { method }\end{array}$} & \multicolumn{2}{|c|}{ Heights $(\mathrm{cm})$} & \multirow{2}{*}{\multicolumn{2}{|c|}{$\begin{array}{c}\text { Grain yield } \\
\left(\mathrm{kg} \mathrm{ha}^{-1}\right)\end{array}$}} & \multirow{3}{*}{$\begin{array}{l}\text { Number of } \\
\text { ears ha }\end{array}$} & \multirow{2}{*}{\multicolumn{2}{|c|}{ Number of kernels ear ${ }^{-1}$}} & \multirow{3}{*}{$\begin{array}{l}\text { 100-kernel } \\
\text { weight }(\mathrm{g})\end{array}$} \\
\hline & \multirow[b]{2}{*}{ Plant } & \multirow[b]{2}{*}{ Ear } & & & & & & \\
\hline & & & $\begin{array}{c}\text { Absolute } \\
(\mathrm{kg})\end{array}$ & $\begin{array}{c}\text { Relative } \\
(\%)\end{array}$ & & $\begin{array}{l}\text { Absolute } \\
(\mathrm{kg})\end{array}$ & $\begin{array}{c}\text { Relative } \\
(\%)\end{array}$ & \\
\hline Two hoeings & $193 \mathrm{a}$ & $100 \mathrm{a}$ & $6,848 \mathrm{a}$ & 129 & $50,427 \mathrm{a}$ & $424 \mathrm{a}$ & 116 & $35.4 \mathrm{a}$ \\
\hline $\begin{array}{l}\text { Intercropped with } \\
\text { gliricidia, sown at } \\
10 \text { seeds } \mathrm{m}^{-2}\end{array}$ & $200 \mathrm{a}$ & $103 \mathrm{a}$ & $6,332 \mathrm{ab}$ & 119 & $49,123 \mathrm{a}$ & $408 \mathrm{ab}$ & 111 & $34.0 \mathrm{a}$ \\
\hline $\begin{array}{l}\text { Intercropped with } \\
\text { gliricidia, sown at } \\
20 \text { seeds } \mathrm{m}^{-2}\end{array}$ & $194 \mathrm{a}$ & $99 \mathrm{a}$ & $5,777 \mathrm{ab}$ & 108 & $48,167 \mathrm{a}$ & $386 \mathrm{bc}$ & 105 & $34.0 \mathrm{a}$ \\
\hline No hoeing & $196 \mathrm{a}$ & $101 \mathrm{a}$ & $5,327 \mathrm{~b}$ & 100 & $48,301 \mathrm{a}$ & $367 \mathrm{c}$ & 100 & $33.2 \mathrm{a}$ \\
\hline CVsubplots, \% & 6.8 & 5.1 & & & 5.3 & & & 8.2 \\
\hline
\end{tabular}

${ }^{1 /}$ In the columns, means followed by the same letter do not differ from one another at $5 \%$ probability by Tukey's test.

differences in grain yield were due to the differences in the number of kernels per ear, since the weed control methods did not differ from one another with regard to the other two grain yield components (Table 5). Other authors (Silva et al., 2009b) have reported similar results. As weeds compete with crops for water, light, nutrients, and space, smaller corn plants are expected in plots where no weed control is performed. When no differences in plant height and ear height are observed in hoed and non-hoed corn in competition with weeds, corn plants may show some degree of etiolation, at least in their initial growth stages. At these stages corn competition with weeds for light should be higher. Etiolation is the development of shoots, branches, or their parts in the absence of light, which usually causes elongated growth with a yellow or white color resulting from the lack of chlorophyll (Hartmann \& Kester, 1990).
For some traits used to assess green corn yield (Table 3) and grain yield (Table 5), intercropping with gliricidia produced intermediate means between those obtained in hoed and non-hoed plots. In addition, the $b$ values in the equations $\mathrm{y}_{1}^{2}=2338020000+$ $12356700 \mathrm{x}^{0.5}\left(\mathrm{R}^{2}=0.97\right)$ and $\mathrm{y}_{2}=11254.8+$ $60.5 \times\left(R^{2}=0.99\right)$, which establish a relationship between gliricidia seeding density $(\mathrm{x})$ and the total number of green ears $\left(\mathrm{y}_{1}\right)$ or gliricidia seeding density $(\mathrm{x})$ and the weight of marketable unhusked green ears $\left(\mathrm{y}_{2}\right)$, were significant at 10 and $5 \%$ probability by the $t$ test, respectively. These facts indicate that intercropping with gliricidia was, in part, beneficial to corn, since it did not have a complete weed control. Similar beneficial effects have been observed by other authors (Silva et al., 2009b), when corn was intercropped with gliricidia by transplanting seedlings of this legume. The data obtained 
in the present study reveal that gliricidia transplanting can be replaced with direct sowing, which is a faster, easier, and more economic system, although it requires a higher number of seeds. These data also demonstrate that increased gliricidia seeding density enhanced the benefits to corn, at least for some traits. As the planting density of the intercropped species increased, reductions in weed density and biomass have also been observed by other authors (Fujiyoshi et al., 2007; Aladesanwa \& Adigun, 2008).

The lowest means of almost all evaluated traits were observed in non-hoed corn. This may have occurred due to corn competition with weeds for water, light, and nutrients (Carruthers et al., 1998), but also or mainly because weeds cause reductions in the corn root system and leaf area (Silva et al., 2009c) and may produce allelopathic substances that may be harmful to corn (Rajcan \& Swanton, 2001). For similar reasons, gliricidia may have benefited corn, negatively influencing the weeds. At least 15 toxic substances were identified in the above-ground part of gliricidia that could have allelopathic action (Ramamoothy \& Paliwal, 1993). Although in the present work intercropping with gliricidia did not significantly reduce weed growth, such a reduction occurred when cotton was intercropped with gliricidia (Silva et al., 2009a).

There were no effects of the cultivars $x$ weed control interaction on the evaluated traits. The cultivars did not influence weed growth, but they produced different gliricidia stands. Cultivar BM 2022 had the best results for the total number of ears and the number and weight of marketable husked ears. Together with cultivar AG 1051, this cultivar had the highest total weight and marketable unhusked ear weight. However, the cultivars did not differ with respect to grain yield. The highest green ear and corn grain yields were obtained with two hoeings; in some traits used to evaluate green ear yield and grain yield, intercropping provided intermediate means as compared to those obtained in hoed and nonhoed plots, indicating that gliricidia was partially beneficial to corn. Increased gliricidia seeding density enhanced the benefits to corn. The lack of hoeing produced the poorest green ear and grain yields.

\section{LITERATURE CITED}

ALADESANWA, R. D; ADIGUN, A. W. Evaluation of sweet potato (Ipomoea batatas) live mulch at different spacings for weed suppression and yield response of maize (Zea mays L.) in Southwestern Nigeria. Crop Protec., v. 27, n. 6, p. 968-975, 2008.

BARTLETT, M. S. Some examples of statistical methods of research in agriculture and applied biology. J. Roy. Stat. Soc., v. 4, n. 1, p. 137-183, 1937.

BARTLETT, M. S. The use of transformations. Biometrics, v. 3, n. 1, p. 39-52, 1947.

BEGNA, S. H. et al. Morphology and yield response to weed pressure by corn hybrids differing in canopy architecture.

Eur. J. Agron., v. 14, n. 3, p. 293-302, 2001

BORGHI, E. et al. Influência da distribuição espacial do milho e da Brachiaria brizantha consorciados sobre a população de plantas daninhas em sistema plantio direto na palha.

Planta Daninha, v. 26, n. 3, p. 559-568, 2008.

BUHLER, D. D. Weed population responses to weed control practices. I. Seed bank, weed populations, and crop yields.

Weed Sci., v. 47, n. 4, p. 416-422, 1999.

CARMO FILHO, F.; OLIVEIRA, O. F. Mossoró: um município do semi-árido nordestino. Mossoró: Fundação Guimarães Duque/ESAM, 1989. 62 p. (Coleção

Mossoroense, Série B., 672).

CARRUTHERS, K. et al. Intercropping corn with soybean, lupin and forages: weed control by intercrops combined with interrow cultivation. Eur. J. Agron., v. 8, n. 3/4, p. 225-238, 1998.

DRUMOND, M. A.; CARVALHO FILHO, O. M. Espécies vegetais exóticas com potencialidades para o semi-árido brasileiro. Brasília: Embrapa Semi-Árido/Embrapa Informação Tecnológica, 2005. 340 p.

EMPRESA BRASILEIRA DE PESQUISAAGROPECUÁRIA - EMBRAPA. Centro Nacional de Pesquisa do Solo. Sistema brasileiro de classificação de solos. Brasília: Serviço de Produção de Informação, 1999. 412 p.

FAO. Soil map of the world; revised legend. Rome: UNESCO, 1988. 119 p.

FUJYOSHI, P. T.; GLIESSMAN, S. R.; LANGENHEIM, J. $H$. Factors in the suppression of weeds by squash interplanted in corn. Weed Biol. Manag., v. 7, n. 1, p. 105-114, 2007.

HARTMANN, H. T; KESTER, D. E. Propagación de plantas: principios y practicas. México, D. C.: Continental, 1990. $760 \mathrm{p}$. 
HOLLANDER, N. G; BASTIAANS, L.; KROPFF, M. J. Clover as a cover crop for weed suppression in a intercropping design. II. Competitive ability of several clover species. Eur. J. Agron., v. 26, n. 1, p. 104-112, 2007.

JANDEL. Jandel TBLCURVE. Table Curve 3.0. Curve fitting software. Corte Madera: Jandel Scientific, 1992. 280 p.

KAMARA, A. Y. et al .Selective control of weeds in an arable crop by mulches from some multipurpose trees in

Southwestern Nigeria. Agrof. Syst., v. 50, n. 1, p. 17-26, 2000.

KUCHINDA N. C. et al. On-farm evaluation of improved maize varieties intercropped with some legumes in the control of Striga in the Northern Guinea savanna of Nigeria. Crop Protec., v. 22, p. 533-538, 2003.

MORAES, P. V. D. et al. Manejo de plantas de cobertura no controle de plantas daninhas na cultura do milho.

Planta Daninha, v. 27, n. 2, p. 289-296, 2009.

OBANDO, L. Potencial alelopático de Gliricidia sepium (Jacq.) Walp. sobre los cultivos de maiz y frijol y las malezas predominantes (abstract). In: WITHINGTON, D.; GLOVER, N.; BREWBAKER, J. L. (Ed.). Gliricidia sepium (Jacq.) Walp.: management and improvement. Proceedings of an Internacional Workshop at Centro Agronómico Tropical De Investigacion y Enseñanza (CATIE), Turrialba, Costa Rica, 1987. Wiamanalo, Nitrogen Fixing Tree Association (NFTA), 1987. 255 p. p.59-60. (Special NFTA Publication, 87-01).

OLASANTAN, F. O; LUCAS, E. O,; EZUMAH, H. C. Effects of intercropping and fertilizer application on weed control and performance of cassava and maize. Field Crops Res., v. 39, n. 1, p. 63-69, 1994.
RAJCAN, I.; SWANTON, C. J. Understanding maize-weed competition: resource competition, light quality and the whole plant. Field Crops Res., v. 71, n. 2, p. 139-150, 2001.

RAMAMOORTHY, M; PALIWAL, K. Allelopathic compounds of Gliricidia sepium (Jacq) Kunth ex Walp. and its effect on Sorghum vulgare L. J. Chem. Ecol., v. 19, n. 8, p. 1691-1701, 1993.

RIBEIRO JÚNIOR, J. I. Análises estatísticas no SAEG Viçosa, MG: Universidade Federal de Viçosa, 2001.

$301 \mathrm{p}$.

SILVA, P. S. L. et al. Weed control via intercropping with gliricidia. I. Cotton crop. Planta Daninha, v. 27, n. 1. p. 97-104, 2009a.

SILVA, P. S. L. et al. Weed control via intercropping with gliricidia. II. Corn crop. Planta Daninha, v. 27, n. 1. p. $105-112,2009$ b.

SILVA, P. S. L. et al. Growth and yield of corn grain and green ear in competition with weeds. Planta Daninha, v. 27, p. 947-955, 2009c. (Number Especial)

SINOQUET, H.; CALDWELL, R. M. Estimation of light capture and partitioning in intercropping systems. In: SINOQUET, H.; CRUZ, P., (Eds.). Ecophysiology of tropical intercropping. Paris: Institute National de la Reserche Agronomique (INRA), 1995. p. 79-80

SKÓRA NETO, F. Controle de plantas daninhas através de coberturas verdes consorciadas com milho. Pesq. Agropec. Bras., v. 28, n. 10, p. 1165-1171, 1993. 